\title{
Effect of cooperative learning on undergraduate nursing students' self-esteem: A quasi- experimental study
}

\author{
Mona M. Megahed ${ }^{1}$, Fathia A. Mohammad ${ }^{2}$ \\ 1. Nursing Department, College of Applied Medical Sciences, King Khalid University, Abha, Saudi Arabia. 2. Medical- \\ Surgical nursing department, faculty of Nursing, Zagazig University, Zagazig, Egypt.
}

Correspondence: Mona M. Megahed. Address: College of Applied Medical Sciences, King Khalid University, Saudi Arabia. Email: malbsuone@kku.edu.sa

Received: March 30, 2014

Accepted: July 20, 2014

Online Published: August 24, 2014

DOI : $10.5430 /$ jnep.v4n11p1

URL: http://dx.doi.org/10.5430/jnep.v4n11p1

\section{Abstract}

Background: Cooperative learning means method which learners work in a small group member and take advantages of each other's expertise to achieve a common goal, and promote higher self-esteem which is an important quality and an attribute considered as specific requirement for better performance and interpersonal success.

Objective: Evaluate effect of cooperative learning on undergraduate nursing students' self-esteem, as well as assessing their attitude regarding cooperative learning.

Methods: Quasi-experimental study was conducted along the second semester, academic year 2012/2013, at college of applied medical sciences, king Khalid University, Saudi Arabia. Total number of 61 female nursing students enrolled in growth\& development course divided into two groups experimental group (32 students) and control group (29 students) was the study sample. Three tools of data collections were used: Preliminary sheet, Rosenberg's self-esteem scale with high reliability (Cronbach's alpha coefficient $r=0.844$ ) and Likert rating attitude scale, its reliability (Cronbach's alpha coefficient $r=0.771$ ).

Results: Students' mean age was $20.8 \pm .983$. Total students' self-esteem pretest was low. The results indicated improvement of the experimental group self-esteem and presence of highly statistical significant differences between experimental and control group posttest $p<.001 .62 .5 \%$ and $68.8 \%$ of the experimental group strongly agree that cooperative learning enhanced students' social skills and responsibility.

Conclusion: The study findings reflected low self-esteem between nursing students. Cooperative learning method is an effective teaching approach improved their self-esteem and it is highly recommended instructional pedagogy prepared students for lifelong learning.

\section{Key words}

Cooperative learning, Nursing students, Self-esteem

\section{I ntroduction}

Lecture is the most common instruction method at higher education level, which encourages individual study but does not promote competences required to prepare graduates to labor market ${ }^{[1]}$. Teaching methods such as discussion and Published by Sciedu Press 
cooperative could be options for teachers seeking to improve student learning, that there's efforts to change teachercentered approaches to student - centered approaches to provide them with greater skills and knowledge ${ }^{[2]}$.

Cooperation is a physiology of interaction and personal lifestyle where individuals are responsible for their actions, including learning and respect the abilities and contributions of their peers. Cooperative learning means a small dedicated group of students learn together and take advantages of each other's expertise to achieve a common goal ${ }^{[3]}$. CL is defined as students working in mixed -ability groups on clearly defined tasks with the expectation that they will be rewarded on the basis of group success ${ }^{[4]}$.

Cooperative learning in universities is based on the theories of cognitive development, behavioral learning and social interdependence ${ }^{[5]}$. CL has been linked to a range of positive social, effective and psychological outcomes, including social support, the quality of students' relationships, attitude to learning, learning skills and self-esteem ${ }^{[6]}$. And several studies also suggest that students who work together in groups tend to have better learning outcomes ${ }^{[7]}$.

Cooperative learning means method which learners work in a small group members or teams which contain 3 to 6 students with heterogeneous capacities work together until attain goal that both whole group get it. Group work is highly appreciated by students as a means of learning and preparing for future work ${ }^{[8]}$.

Cooperative learning consists of five basic elements: positive independence, promote interaction, individual accountability, teaching of interpersonal and social skills and quality of group processing. CL has demonstrated the academic, social, affective and psychological growth of students who work together in groups ${ }^{[9]}$. The benefits of cooperative learning include higher academic achievement, better high- level reasoning and critical thinking skills, lower levels of anxiety and stress, greater intrinsic motivation to learn and achieve more positive attitudes toward subject areas, and higher selfesteem $^{[10]}$.

Self-esteem refers to the extent to which individuals value themselves ${ }^{[11]}$. Self-esteem is the one key ingredient that affects the level of proficiency in all fields of endeavor, and has been correlated to: job success, school achievement, interpersonal compatibility, and general happiness ${ }^{[12]}$.

Self-esteem is defined as appositive or negative orientation toward oneself and a predictor of adjustment to stress ${ }^{\text {[13] }}$. Nursing is recognized as a stressful occupation, the problem of stress does not begin when the nurse qualified, but during education and training ${ }^{[14,15]}$.

High levels of self-esteem are important in terms of both managing the demands placed on nurses during their training and for developing a strong and therapeutic relationship with patient ${ }^{[16]}$. Self-esteem is an important quality and an attribute considered as specific requirement for nurses, high self-esteem causes better performance and interpersonal success leading to improved happiness and healthy lifestyle associated with increased self-efficacy, body image and leader$\operatorname{ship}^{[17]}$.

Evidence suggests that cooperative learning yields increased efforts among students, more positive interpersonal relationships, and improved mental health when compared to purely individualistic learning ${ }^{[18]}$.

\subsection{Aim of the study}

The present study was conducted to evaluate effect of cooperative learning on undergraduate nursing students self-esteem, and assess their attitude regarding cooperative learning, as it is the first time for application of cooperative learning method among these students.

\subsection{Research hypotheses}

The cooperative learning method is effective to improve self-esteem among under graduate nursing students. 


\section{Methods}

\subsection{Research design}

Quasi- experimental study was conducted along the second semester from February to June, academic year 2012/2013.

\subsection{Study setting and subjects}

The study was conduct among Saudi undergraduate female nursing students at nursing department, college of applied medical sciences, king Khalid University.

Total number of 61 students, level six enrolled in growth\& development course was the study sample. The 61 students divided into two groups 32 students (experimental group) and 29 students (control group) the experimental group divided into 8 heterogeneous subgroups every group include 4 students varies in their academic abilities.

\subsection{Tools of data collection}

Tool (1): Preliminary sheet which include team names, age, GPA, roles and responsibilities (coordinator, recorder, monitor and checker), and times available for group work

Tool (2): Rosenberg's self-esteem scale (Rosenberg, 1965) ${ }^{[19]}$ which is the most widely scale used to measure global selfesteem by measuring positive and negative feelings about self, all items are answered using 4- point Likert scale format ranging from strongly agree to strongly disagree, it is a 10- item scale with high reliability (Cronbach's alpha coefficient $r$ $=0.844)$

Scoring: Scores are calculated as follows for items 1, 2, 4, 6 and 7: strongly agree allotted 3 points, 2 points to agree, 1 point to disagree and strongly disagree 0 . For items 3, 5, 8, 9 and 10: strongly agree got (0), agree (1), disagree (2) and strongly disagree (3). The total cores are calculated ranged from 0-30. Scores between 15- 25 are with normal range; scores below 15 are low self-esteem.

Tool (3): Likert rating attitude scale: the ten scale statements developed by researcher to assess students' responses towards cooperative learning, the scale consisted of four responses for each statement; strongly agree, agree, disagree, and strongly disagree, it’s reliability (Cronbach’s alpha coefficient $r=0.771$ )

\subsection{Field work}

- A review of the current national and international related literature was done by the researcher to be acquainted with the research problem.

- After all students had introduction about the course they will study (growth \& development) which is a theory course included all periods of development, the researcher divided them into experimental and control group, experimental group was taught by cooperative learning method. The control group was taught by traditional lecture method.

- The Rosenberg's self-esteem scale sheet was distributed to all students (experimental and control group) to fill it (pretest), within a time ranged from $10-15$ minutes.

- $\quad$ Preliminary sheet which include team names, roles and responsibilities (coordinator, recorder, monitor and checker), and times available for group work was distributed and experimental group (8 teams) asked to fill it, and the researcher guide them about instructions.

- At the end of the course, the Rosenberg's self-esteem scale sheet was distributed to all students (experimental and control group) to fill it (posttest). Likart rating attitude scale distributed to the experimental group to fill it. 


\subsection{Ethical consideration}

- An official permission with written letter clarifying purpose of the study was obtained from the dean of the college to conduct the field work of the study.

- The researcher explained the aim of the study to the students included in the study, assured maintaining anonymity and confidentiality of the subjects' data.

\subsection{Statistical method for analysis}

Data entry inserted using SPSS statistical software packages version 18. Data was presented using descriptive statistics in the form of frequencies and percentages for qualitative variables, and means and standard deviations for quantitative variables. Quantitative variables for groups were compared using T. test. Significant difference is considered at $p<.05$.

\section{Results}

Table 1 revealed that students' mean age was $20.8+.983$. As regards GPA mean score, the experimental group GPA mean score was 3.37 while control group GPA mean score was 3.29 .

Table 1. Participants' General Characteristics $(\mathrm{n}=61)$

\begin{tabular}{ll}
\hline Items & Mean score $(\overline{\mathrm{X}} \pm$ SD $)$ \\
\hline Age & $20.8 \pm .983$ \\
GPA & \\
Experimental $(\mathrm{n}=32)$ & $3.37 \pm 0.712$ \\
Control $(\mathrm{n}=29)$ & $3.29 \pm 0.442$ \\
\hline
\end{tabular}

Table 2 summarizes students' self-esteem according to Rosenberg's Self-Esteem Scale, low self-esteem among experimental and control groups represented 56.3\% and 55.2\% respectively. Experimental group mean score was18.28 \pm 5.41 , while control group mean score was $19.4 \pm 5.29$, and there is no significant difference between two groups pretest.

Table 2. Participants’ self-esteem according to Rosenberg’s Self-Esteem Scale pretest

\begin{tabular}{|c|c|c|c|}
\hline \multicolumn{2}{|l|}{ Items } & No & $\%$ \\
\hline $\begin{array}{l}\text { Experimental group } \\
(\mathrm{n}=32)\end{array}$ & $\begin{array}{l}\text { Normal Self-Esteem } \\
\text { Low Self-Esteem }\end{array}$ & $\begin{array}{l}14 \\
18 \\
\end{array}$ & $\begin{array}{l}43.8 \\
56.3 \\
\end{array}$ \\
\hline \multicolumn{2}{|c|}{$\overline{\mathrm{X}}_{ \pm \mathrm{SD}}$} & \multicolumn{2}{|l|}{$18.28 \pm 5.41$} \\
\hline Control group $(\mathrm{n}=29)$ & $\begin{array}{l}\text { Normal Self-Esteem } \\
\text { Low Self-Esteem }\end{array}$ & $\begin{array}{l}13 \\
16 \\
\end{array}$ & $\begin{array}{l}44.8 \\
55.2\end{array}$ \\
\hline \multicolumn{2}{|c|}{$\overline{\mathrm{X}}_{ \pm \mathrm{SD}}$} & \multicolumn{2}{|l|}{$19.4 \pm 5.29$} \\
\hline Paired $t$-test & & $T=.850$ & \\
\hline
\end{tabular}

Note. Significance level $p<.05$

The results indicated the presence of highly statistical significant differences between experimental and control group posttest. Experimental group self-esteem mean score was $23.75 \pm 3.46$, however control group self-esteem mean score was19.65 \pm 4.70 (see Table 3).

Table 3. Participants' self-esteem means score posttest

\begin{tabular}{cc}
\hline Items & $\overline{\mathrm{X}} \pm$ SD \\
\hline Experimental group $(\mathrm{n}=32)$ & $23.75 \pm 3.46$ \\
Control group $(\mathrm{n}=29)$ & $19.65 \pm 4.70$ \\
Paired $t$-test & $T=3.894 P<.001^{*}$ \\
\hline
\end{tabular}

Note. Significance level $p<.05$ 
Table 4 shows experimental group strongly agree toward cooperative learning promotes friendship among students, enhanced learning, helps students obtain a deeper understanding, felt students responsible for the success of each individual in the group, enhances students' social skills and for $50.0 \%, 53.1 \%, 56.3 \%, 59.4 \%$, and $62.5 \%$ respectively, while $3.1 \%$ disagree that cooperative learning enhances the learning of low-ability students.

Table 4. Experimental group response toward Cooperative Learning $(\mathrm{n}=32)$

\begin{tabular}{|c|c|c|c|c|c|c|}
\hline \multirow{2}{*}{ Items } & \multicolumn{2}{|c|}{ Strongly Agree } & \multicolumn{2}{|c|}{ Agree } & \multicolumn{2}{|c|}{ Disagree } \\
\hline & No & $\%$ & No & $\%$ & No & $\%$ \\
\hline Using cooperative learning promotes friendship among students. & 16 & 50.0 & 16 & 50.0 & 0 & 0 \\
\hline The cooperative learning experiences in my class enhanced my learning. & 17 & 53.1 & 15 & 46.9 & 0 & 0 \\
\hline Peer interaction helps students obtain a deeper understanding of the material. & 18 & 56.3 & 11 & 34.4 & 3 & 9.4 \\
\hline $\begin{array}{l}\text { The cooperative learning approach forced me to take on more responsibility } \\
\text { for learning. }\end{array}$ & 12 & 37.5 & 20 & 62.5 & 0 & 0 \\
\hline Cooperative learning enhances the learning of low-ability students. & 15 & 46.9 & 16 & 50.0 & 1 & 3.1 \\
\hline Engaging in cooperative learning enhances students’ social skills. & 20 & 62.5 & 12 & 37.5 & 0 & 0 \\
\hline Cooperative learning prepares students for the real world. & 9 & 28.1 & 23 & 71.9 & 0 & 0 \\
\hline I felt responsible for the success of each individual in the group. & 19 & 59.4 & 12 & 37.5 & 1 & 3.1 \\
\hline I felt responsible to my group. & 22 & 68.8 & 10 & 31.3 & 0 & 0 \\
\hline The groups were structured so that multiple points of view were represented. & 15 & 46.9 & 11 & 34.4 & 6 & 18.8 \\
\hline
\end{tabular}

\section{Discussion}

Cooperative Learning (CL) is defined as students working in mixed- ability groups on clearly defined tasks with the expectation that they will be rewarded on the basis of group success through interrogating issues, sharing ideas and clarifying them and therefore constructing new knowledge ${ }^{[8]}$.

The current study was conducted to evaluate effect of cooperative learning on undergraduate nursing students' self-esteem, and assessing their attitude regarding cooperative learning. As regards general characteristics of the study sample, the mean age of students was $20.8 \pm .983$. The present study revealed that more than half of students had low self-esteem according to Rosenberg's Self-Esteem Scale, and there is no significant difference of studied nurses' self-esteem among control and experimental group pretest. This result goes in line with another study conducted among nursing students to evaluate their self-esteem, and shows low levels of self-esteem among study sample ${ }^{[20]}$.

In study conducted to compare between traditional versus cooperative learning method, it showed that students lean to show the most academic achievement, insolubility in academic critical thinking skills, reasoning level, the deepest taught materials and the least moral behaviors in class and the most focus on task, the least stress level, the most internal motivation in learning, the most capacity in viewing situation behalf others' view, the most positive and supporting communication with peers and self-esteem ${ }^{[21]}$. This explained the results of present study which indicated that experimental group self- esteem mean score improved post intervention and presence of highly significant differences between experimental and control group posttest. Also another studies mentioned that cooperative learning approach has also been reported to promote more positive student attitudes toward their learning and develop self-esteem, cohesiveness, and learning skills ${ }^{[9,22,23]}$. Also (Johnson\& Johnson, 2005) ${ }^{[24]}$ reported that cooperative learning facilitates greater improvement in self-esteem than individualistic learning environment. Moreover in some studies students' self-esteem increased in cooperative situations because students were involved in cooperative efforts ${ }^{[25-27]}$.

In relation to study sample attitude regarding cooperative learning, the results of current study showed that more than half of them strongly agree that cooperative learning promotes friendship among students, enhanced learning, helps students to obtain a deeper understanding, felt students responsible for the success of each individual in the group, and enhances 
students' social skills. This result goes in line with other studies which show a moderate enthusiasm for working in groups and the participants disclose both positive and negative experiences of this mode of working ${ }^{[28,29]}$. Additional studies showed that students seem to prefer group work as a means of learning and well-being, but also emphasize that their learning profits from collaboration in groups ${ }^{[30,31]}$.

\section{Conclusion \& recommendations}

Self-esteem considered as a specific requirement for health team members. Nursing students' experience a wide range of difficult situations that impact on their personality than students in other fields; they need to be in high level of their self-esteem during teaching and training. The current study reflected low self-esteem between nursing students (experimental \& control group) pretest. Cooperative learning is an effective teaching approach that improved experimental group self-esteem, which reflect a positive impact of cooperative leaning on nursing students' self-esteem, and there is positive attitude among experimental group. Cooperative learning is highly recommended instructional pedagogy prepared students for lifelong learning.

\section{Acknowledgments}

The author would like to thank and appreciate all nursing students at College of Applied Medical Sciences, King Khalid University, especially level six for their sincere cooperation.

\section{References}

[1] Senocak E. Development of an instrument for assessing under graduate science students' perceptions: the problem based learning environment inventory. Journal of Science Education and Technology. 2009; 18: 560-569. http://dx.doi.org/10.1007/s10956-009-9173-3

[2] Thanh-Pham T. Group composition of cooperative learning: does heterogeneous grouping work in Asian classrooms? International Education Studies. 2010; 3(3): 12-19.

[3] Amita M A. Families, Children and communities in a multicultural and diverse society. Research paper on curricular models, Nova southeastern university. 2006.

[4] Ruiz-Gallardo R, Lopez- Cirugeda I, Moreno- Rubio C. Influence of cooperative learning on students' self -perception on leadership skills: a case study in science education. Higher Education Studies. 2012; 2(4): 40-48. http://dx.doi.org/10.5539/hes.v2n4p40

[5] Morgan B. Cooperative learning in higher education: undergraduate student reflections on group examinations for group grades. College Student Journal. 2003; 37(1): 40-50.

[6] Bertucci A, Conte S, Johnson DW, Johnson RT. The impact of size of cooperative group on achievement, social support, and self-esteem. The Journal of General Psychology. 2010; 137(3): 256-271. PMid:20718226 http://dx.doi.org/10.1080/00221309.2010.484448

[7] Alandeom O, Sadler T. Interactive patterns and conceptual convergence during students' collaborations in science. Journal of Research in Science Teaching. 2008; 26: 634-658.

[8] Gilles R, Boyle M. Teachers' reflections on cooperative learning: issues of implementation. Teaching and Teacher Education. 2010; 26: 933-940. Available from: http://dx.doi.org/10.1016/j.tate.2009.10.034. http://dx.doi.org/10.1016/j.tate.2009.10.034

[9] Johnson DW, Johnson RT. Social Independence Theory and cooperative learning: the teacher's role. In R.M.Gillies, A.Ashman\& J.Terwel(Eds), teacher's role in implementing cooperative learning in the class room(pp.9-37).New york, U.S.A: Springer. 2008: http://dx.doi.org/10.1007/978-0-387-70892-8_1

[10] Springer L, Stanne M F, Donovan S. Effects of small- group learning on undergraduates' science, mathematics, engineering, and technology: meta- analysis. National institute for science education: 2006; Madison, WI, 1997; Available from: http://www.wcer.wisc.edu/nise/CL1/CL/resource/R2.htm.

[11] Reber AS, Reber E. The penguin dictionary of psychology. Third ed. Penguin. London; 2001.

[12] Habibollah N, Rohani A, Tengku A, Jamaluddin S. Self-Esteem, gender and academic achievement of undergraduate students. American Journal of Scientific Research. 2009; 3: 26-37. 
[13] Trzesniewski KH, Donnellan M B, Robins RW. Stability of self-esteem across of the life span. Journal of Personality and Social Psychology. 2003; 84(1): 205-220. PMid:12518980 http://dx.doi.org/10.1037/0022-3514.84.1.205.

[14] Mc Vicar A. Workplace stress in nursing: a literature review. Journal of Advanced Nursing. 2003 ; $44(6)$ : 633-642. http://dx.doi.org/10.1046/j.0309-2402.2003.02853.x

[15] RheadM. Stress among student nurses: is it practical or academic? Journal of Clinical Nursing. 1995; 4(6): 369-376. http://dx.doi.org/10.1111/j.1365-2702.1995.tb00038.x

[16] Ohlen J, Segesten K. The professional identity of the nurse: concept analysis and development. Journal of Advanced Nursing. 1998; 28(4): 720-727. http://dx.doi.org/10.1046/j.1365-2648.1998.00704.x

[17] Raty L, Gustafsson B. Emotions in relation to healthcare encounters affecting self-esteem. J Neurosci Nurs. 2006; 38(1): 42-50. http://dx.doi.org/10.1097/01376517-200602000-00009

[18] Attle S, Baker B. Cooperative learning in a competitive environment: classroom applications. International Journal of Teaching and Learning in Higher Education. 2007; 19(1): 77-83.

[19] Rosenberg M. society and the adolescent self- image. Princeton, NI: Princeton University Press; 1965.

[20] Chris V, Pais M, Kumar S, Sisodia V. Perceived self- esteem amongst first -year nursing students- cross sectional survey, International Journal of Health and Rehabilitation Sciences. 2012; 1(2): 74-79.

[21] Najafi M, Rostamy- Malkhalifeh M, Amiripour P. The effect of efficiency of cooperative learning method on increasing blind students' perception of mathematical conceptions. Journal of Applied Mathematics, Islamic Azad University of Lahijan. 2012; 8(4): 57-63.

[22] Sahin A. Effects of jigsaw III technique on achievement in written expression. Asia Pacific Education Review. 2010; 12(3): 427-435. http://dx.doi.org/10.1007/s12564-010-9135-8

[23] Slavin RE. Instruction based on cooperative learning. In R. E. Mayer \& P.A. Alexander (Eds.), Handbook of Research on learning and Instruction New York: Taylor \& Francis. 2011; 344-360.

[24] Johnson DW, Johnson RT. New developments in social interdependence Theory. Genetic, Social \&General Psychology Monographs. 2005; 131(4): 285-358. PMid:17191373 http://dx.doi.org/10.3200/MONO.131.4.285-358

[25] Kilic D. The effect of jigsaw technique on learning the concepts of the principles and methods of teaching. World applied sciences journal. 2008; 4(1): 109-114.

[26] Thanh-Pham T. An investigation of perceptions of Vietnamese teachers and students towards cooperative learning. International education studies. 2011; 4(1): 4-12.

[27] Le TT. Infusing cooperative learning into an EFL classroom. English language Teaching. 2010; 3(2): 64-77.

[28] Peterson S E, Miller J A. Quality of college students' experiences during cooperative learning. Social Psychology of Education. 2004; 7: 161-183. http://dx.doi.org/10.1023/B:SPOE.0000018522.39515.19

[29] Underwood JDM. Student attitudes towards socially acceptable and unacceptable group working practices. British Journal of Psychology. 2003; 94: 319- 337. PMid:14511546 http://dx.doi.org/10.1348/000712603767876253

[30] Hammar- Chiriac E, Granstrom K. Teachers' leadership and students' experience of group work. Teachers and Teaching: Theory and Practice. 2012; 18(3). http:// dx.doi.org/10.1080/00221309.2010.484448.

[31] Tran VD, Lewis R. Effect of cooperative learning on students at Giang University in Vietnam, International Education Studies. 2012; 5(1). 